\title{
A role for estrogen in somatic cell fate of the mammalian gonad
}

\author{
Andrew J. Pask
}

Published online: 8 December 2011

(C) Springer Science+Business Media B.V. 2011

\begin{abstract}
Estrogen is both necessary and sufficient to drive ovarian development in many nonmammalian vertebrates. However, the role of estrogen in the mammalian gonad is less clear. Mouse ovarian development can proceed in the absence of estrogen signaling, but granulosa cell fate cannot be maintained. Estrogen receptor expression is conserved in the indifferent gonad of all mammals and many species also express the CYP19 gene that encodes aromatase, in the early ovary. Furthermore, estrogen is sufficient to drive ovarian development of the indifferent gonad in marsupial mammals. Here we review the function of estrogen in the mammalian gonad and propose a model for its action in establishing and maintaining ovarian somatic cell fate.
\end{abstract}

Keywords estrogen - sex determination - granulosa cell $\cdot$ Sertoli cell $\cdot$ SOX9 $\cdot$ marsupial $\cdot$ eutherian

$\begin{array}{ll}\text { Abbreviations } \\ \text { SOX } & \text { Sry-type HMG box } \\ \text { SRY } & \begin{array}{l}\text { Sex-determining region on the Y } \\ \text { chromosome }\end{array}\end{array}$

Responsible Editors: Tariq Ezaz and Jennifer Graves.

\footnotetext{
A. J. Pask $(\bowtie)$

Department of Molecular and Cell Biology,

The University of Connecticut,

Storrs, CT 06269, USA

e-mail: andrew.pask@uconn.edu
}

\author{
TESCO Testis-specific enhancer of Sox 9 Core \\ element \\ FOXL2 Forkhead box L2 \\ DMRT1 Doublesex and mab-3 related \\ transcription factor 1 \\ ER Estrogen receptor \\ WNT4 Wingless-type MMTV integration site \\ family member 4 \\ RSPO1 R-spondin-1 \\ CYP19 Cytochrome P450 aromatase \\ GSD Genetic sex determination \\ ESD Environmental sex determination \\ NLS Nuclear localization signal
}

\section{Introduction}

The sex-determining switch mechanism that triggers the indifferent gonad to follow either a male or female fate is highly variable in vertebrates, even among closely related taxa (Ferguson-Smith 2007). There are two main categories of switch mechanisms; genetic sex determination (GSD) where gonadal sex is controlled by one or more sex-determining loci, and environmental sex determination (ESD) where gonadal sex is dependent on external environmental stimuli (Solari 1994). GSD is the most prevalent mechanism and is often associated, but not always, with heteromorphic sex chromosomes. Despite its prevalence, very few sex-determining genes have been identified. 
In mice and humans, sex is determined by the $S R Y$ gene that triggers testis differentiation (Koopman et al. 1991; Sinclair et al. 1990), DMRT1 triggers female development in birds (Smith et al. 2009) and Xenopus leavis (Yoshimoto et al. 2008), while a male-specific orthologue $D M Y$ triggers testis development in some medaka fish (Matsuda et al. 2002). The precise molecular mechanism by which ESD triggers gonadal differentiation is even less understood, but there is good evidence that such mechanisms primarily regulate the production of aromatase, the enzyme that synthesizes estrogen from testosterone, to trigger ovarian development (Ramsey and Crews 2009). Despite the highly variable switch mechanisms, the downstream molecular pathways regulating testis and ovarian differentiation are highly conserved across vertebrates, as is the organization of the gonads.

Gonads consist of two complementary cell types: the somatic cells including the supporting cell lineages (the Sertoli cells, Leydig cells, and peritubular myoid cells in the testes and the granulosa cells and theca cells in the ovary) and the germ cells that will become the gametes (spermatozoa in the testes and oocytes in the ovary). The fate of the somatic cells coordinates gonadal differentiation, which in turn regulates the appropriate development of the germ cells (Koubova et al. 2006; Bowles et al. 2006).

In the male gonad, it is the activation of SOXY in the somatic cells that directs Sertoli cell differentiation (Sinclair et al. 1990; Bishop et al. 2000). SOX9 and its gonadal enhancer, TESCO, are highly conserved, suggesting that it maintains a critical function in vertebrate testis development (Bagheri-Fam et al. 2010). SOX9 initially shows a low level of transcription and a cytoplasmic distribution in the indifferent gonad, but translocates to the nucleus in males and is dramatically upregulated (de Santa Barbara et al. 2000; El Jamil et al. 2008; Morais da Silva et al. 1996). In mammals, expression of the Y-linked sex-determining gene SRY triggers SOX9 upregulation in the gonad (Sekido and Lovell-Badge 2008), where it acts as a transcriptional activator of the testis differentiation pathway. The nuclear translocation of SOX9 is both necessary and sufficient for Sertoli cell development in mice (Qin et al. 2004; Bishop et al. 2000), and is the most critical step in the initiation of the testis pathway. However, even after testicular fate is established, the Sertoli cell phenotype remains plastic. In mice, expression of Dmrt1 is essential to maintain
Sertoli cells (Matson et al. 2011). Loss of Dmrt1 even in adult Sertoli cell leads to upregulation of FoxL2 and transdifferentiation into a granulosa cell phenotype. Thus, viable development of the gonad requires a tightly regulated set of key factors to specify and then maintain gonadal cell identity.

\section{Activation of ovarian development}

In XX mammals, in the absence of SRY, SOX9 expression is low and its protein product is cytoplasmic in the somatic cells of the indifferent gonad. As a result, the testis pathway is not initiated and granulosa cell development is activated. The precise mechanism preventing SOX9 from entering the nucleus and activating the Sertoli cell program in female gonads is unknown, but recent data suggest that estrogen may play an important role in this process (Pask et al. 2010). This is of special interest since a recent increase in male reproductive abnormalities in humans and wildlife, resulting in lower sperm counts and quality and increased rates of hypospadias and testicular dysgenesis, has been attributed to an increased exposure to estrogenic compounds found in the environment (Giwercman et al. 1993; Carlsen et al. 1992).

Historically, the ovary was viewed as the default gonadal state, such that in the absence of SRY, an ovary would passively form. This view has now changed, and a few key ovary-promoting genes have been identified in mice and humans, the most critical of which include WNT4, RSPO1, and FOXL2. Mutations in all three genes result in a failure of normal ovarian formation in mice and humans (Chassot et al. 2008a, b; Heikkila et al. 2001; Uda et al. 2004; Vainio et al. 1999). FoxL2 appears to be critically important in regulating female somatic cell fate since its ablation in adult mouse ovaries leads to transdifferentiation of the granulosa cells to a Sertoli cell phenotype and an upregulation of $S O X 9$ (Uhlenhaut et al. 2009). FoxL2, in conjunction with activated estrogen receptors, is proposed to maintain granulosa cell fate by suppressing $S O X 9$ transcription through binding to its enhancer element, TESCO (Uhlenhaut et al. 2009). Binding sites for FOXL2 and the estrogen receptor are highly conserved in TESCO across mammals, including in the marsupial, tammar wallaby (Fig. 1). Furthermore, FOXL2 has been shown to play a direct role in the upregulation of CYP19 (aromatase; required for the 
TGTCAGAAATGAGCATGAATCT CAATATTAAATTCTATCCTGCTATTTCTTCTTCTTCG TTAAAACTTCAACACCATCATGTAATTA CAATATTTAATATAGGTAATGCTTAGTAGAA GTAGAAGTAATAATAAGCAAGTTAGAAAGAATGGCAATTCAATAGTGACTGGGTTAAAG AAGATCTGGAATCTGCTTTTGTTCCTAACCTGGACAGTTTTTAGAAAAC AACAATACCT TCTTTCAGCAACTGCCAGGAGATCGAAAGGTAGGACTCCTGTTCTCCCAGATAAGAGCT GGCAGAAAGGTGAGTGCCCT CAATACTGGGGAGACATTAACTCTCTGGGGTCAGCTAG CAGCAAACATGCAAA AAATACTCTAGCCCCATTCCAACAA

Fig. 1 Tammar wallaby SOX9 TESCO enhancer. Green = SOX binding sites; yellow = FKHD (FOXL2) binding sites; red = estrogen receptor binding site; purple $=$ GATA binding site; yellow/green $=$ FOX/SOX binding site

synthesis of estrogen from testosterone) in both the fish brain (Sridevi et al. 2011) and indifferent XX goat gonad, where it initiates the synthesis of estrogen, promoting ovarian development (Pannetier et al. 2004).

\section{A conserved role for estrogen}

Estrogen is known to play an essential role in female sex determination in nonmammalian vertebrates regardless of the sex-determining mechanism (Solari 1994; Nakamura 2010). The production of estrogen in the indifferent gonad is controlled by the expression of CYP19, which encodes the aromatase enzyme and causes estrogen production. In the presence of estrogen, the indifferent gonad will follow an ovarian development pathway, while in its absence the gonad will become a testis (Solari 1994). As a result, exogenous estrogen exposure to developing fish, reptile, amphibian, and bird fetuses will trigger ovarian development, while exposure to estrogen inhibitors causes testis development (Solari 1994; Ramsey and Crews 2009). This is in contrast to mammals where SRY triggers testis development and the ovary is the default state. However, in nonmammalian vertebrates, estrogen appears to be the master regulator of ovarian development and in its absence the gonad will default to a testicular fate.

Despite the highly conserved role of estrogen in nonmammalian vertebrates, its function in the development of the mammalian ovary remains less clear. Interestingly, expression of the estrogen receptors, which mediate estrogen actions within the cell, is maintained in the somatic cells of the indifferent gonads of mice, humans, goats, sheep, and marsupials indicative of a highly conserved role for estrogen in the early mammalian gonad (Calatayud et al. 2010). It was a surprising finding then, that estrogen was not required for initial ovarian development in mice (Couse and Korach 1999). Mice deficient for both the alpha and beta estrogen receptors or CYP19 have normal early ovarian differentiation (Britt and Findlay 2003; Britt et al. 2001). However, shortly after birth, germ cells are lost and the somatic cells take on a Sertoli cell phenotype (Fisher et al. 1998; Toda et al. 2001). These Sertoli-like cells express $S O X 9$ and show a characteristic Sertoli cell morphology, with tight junctions, and arrangement (Britt and Findlay 2003). Upon administration of estrogen to aromatase-deficient mice, ovarian histology is restored and $S O X 9$ levels are significantly decreased, along with several other testis markers, to normal female levels (Britt et al. 2004). Together these data show that the somatic cells of the ovary also retain a plasticity that, along with the genes regulating somatic cell differentiation, is directly responsive to estrogen.

While mouse studies have been fundamental in developing a basic understanding of gonadal differentiation, there are differences in gene expression, responses to haploinsufficiency of critical genes and, most importantly, in the role of estrogen in the fetal gonad between mice and other mammals (Wilhelm et al. 2007). Comparative analyses across multiple species can be particularly helpful in isolating critical regulatory networks required for developmental events from those that show species-specific variations (Sanchez et al. 2011; Pounds et al. 2011; Crozat et al. 2010; Lu et al. 2009). Outside of the rodent lineage, upregulation of CYP19 has been reported in the fetal ovary of many eutherian species including goats (Pannetier et al. 2004), sheep (Quirke et al. 2001), and cows (Garverick et al. 2010) suggesting that estrogen may play a central role in its early differentiation. Similarly, in humans, exposure of the developing fetus to potent synthetic estrogenic compounds can dramatically affect male gonadal differentiation (Toppari 2008; Arai et al. 1983). Thus, it appears that gonadal development in rodents may be unusually resistant to a loss of estrogen.

The ability for estrogen to direct ovarian development in mammals has been demonstrated in marsupials 
(Pask et al. 2010; Coveney et al. 2001; Burns 1955). Marsupials have been evolving independently of humans and mice for around 160 million years (Fig. 2; Luo et al. 2011). Sexual differentiation occurs around the time of birth in marsupial, unlike in eutherian mammals where this process occurs in utero. Marsupials develop gonads that are identical in structure to human and mouse gonads and determine sex based on the presence/absence of the SRY-bearing Y chromosome (Pask and Graves 2001). Development of the somatic cell lineages and germ cell entry into either meiotic or mitotic arrest is separated by several days in the tammar wallaby, similar to the developmental timing seen in human, goat, sheep, and cow gonads, whereas in the mouse these events occur concurrently (Harry et al. 1995; Renfree et al. 1996). Thus in marsupials it is possible to examine the effects of exogenous estrogen on the differentiation of the somatic cell lineages ex utero, uncomplicated by changes in germ cell development or the in utero environment.

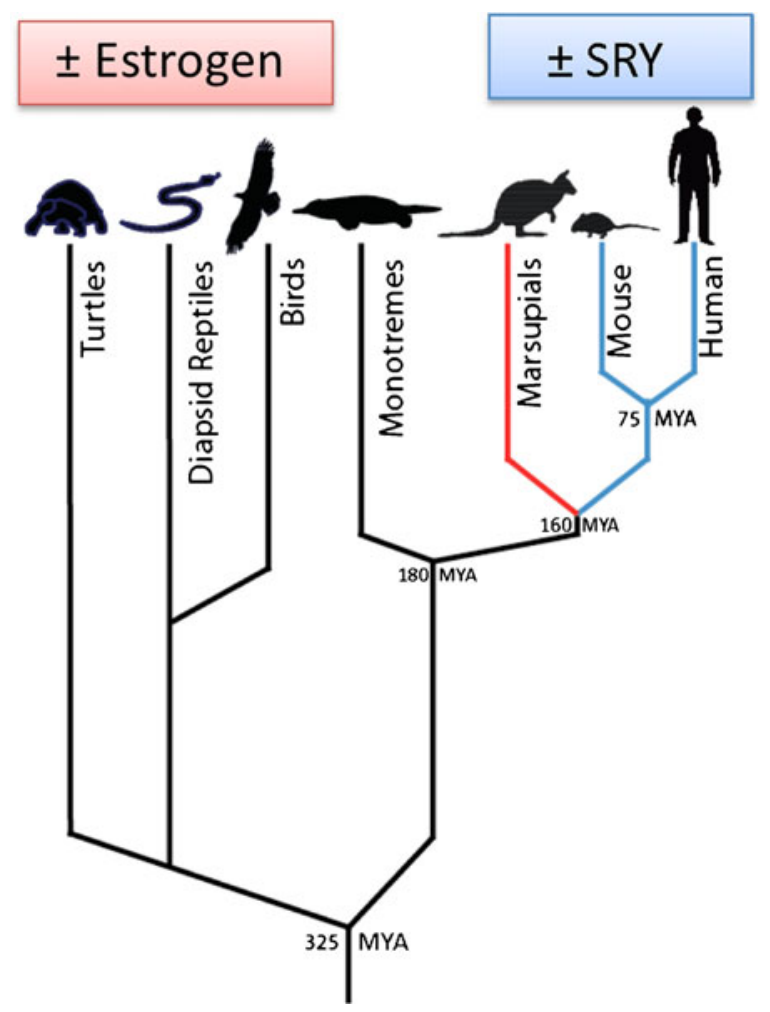

Fig. 2 Phylogenetic tree of the vertebrates showing the divergence of marsupials (red) from mice and humans (eutherian mammals; blue)
Estrogen blocks male development by modulating SOX9

Administration of estrogen to genetically male marsupial neonates causes ovarian development of the gonad (Pask et al. 2010; Coveney et al. 2001; Burns 1955). In the presence of estrogen, key male differentiation genes fail to be upregulated in the $\mathrm{XY}$ gonad and instead, key ovary-promoting genes are upregulated leading to ovarian development (Pask et al. 2010). Estrogen appears to trigger sex reversal through the exclusion of SOX9 from entering the nucleus in the somatic cells of the developing gonad (Pask et al. 2010). In the absence of nuclear SOX9, Sertoli cell development cannot be initiated and the somatic cells follow a granulosa cell fate (Fig. 3).

A conserved role for estrogen-mediating SOX9 action is consistent with several observations in mammals. In mice, Sox 9 is able to autoregulate by binding to its own promoter (Sekido and Lovell-Badge 2008). However, despite Sox 9 expression in the somatic cells of the adult mouse ovary, it does not become upregulated (Notarnicola et al. 2006). High levels of estrogen could prevent the nuclear translocation of SOX9 in adult female gonads, preventing its own upregulation. Conversely, Sox 9 is upregulated in the absence of estrogen in aromatase-deficient mice ovaries, suggesting it can translocate to the nucleus to propagate its own transcription. However, when these mice are exposed to exogenous estrogen the effect is reversible, and $\operatorname{Sox} 9$ is repressed (Britt et al. 2002; de Santa Barbara et al. 2000). Data from marsupials would suggest that this repression occurs by trapping SOX9 in the cytoplasm preventing its autoregulation. Furthermore, activated estrogen receptors, in conjunction to FoxL2, could directly suppress SOX9 transcription through binding to TESCO (Uhlenhaut et al. 2009). Either way, in mammals, estrogen still remains a critical factor in maintaining ovarian somatic cell fate. This fundamental role of estrogen is also consistent with observations in nonmammalian vertebrates. In the presence of estrogen, SOX9 remains cytoplasmic in the early developing gonads of many nonmammalian vertebrates, permitting granulosa cell development (de Santa Barbara et al. 2000). However, in the absence of estrogen, SOX9 becomes nuclear and Sertoli cell development is initiated (Sim et al. 2008). Therefore, the ability of estrogen to mediate the subcellular localization of SOX9 and 


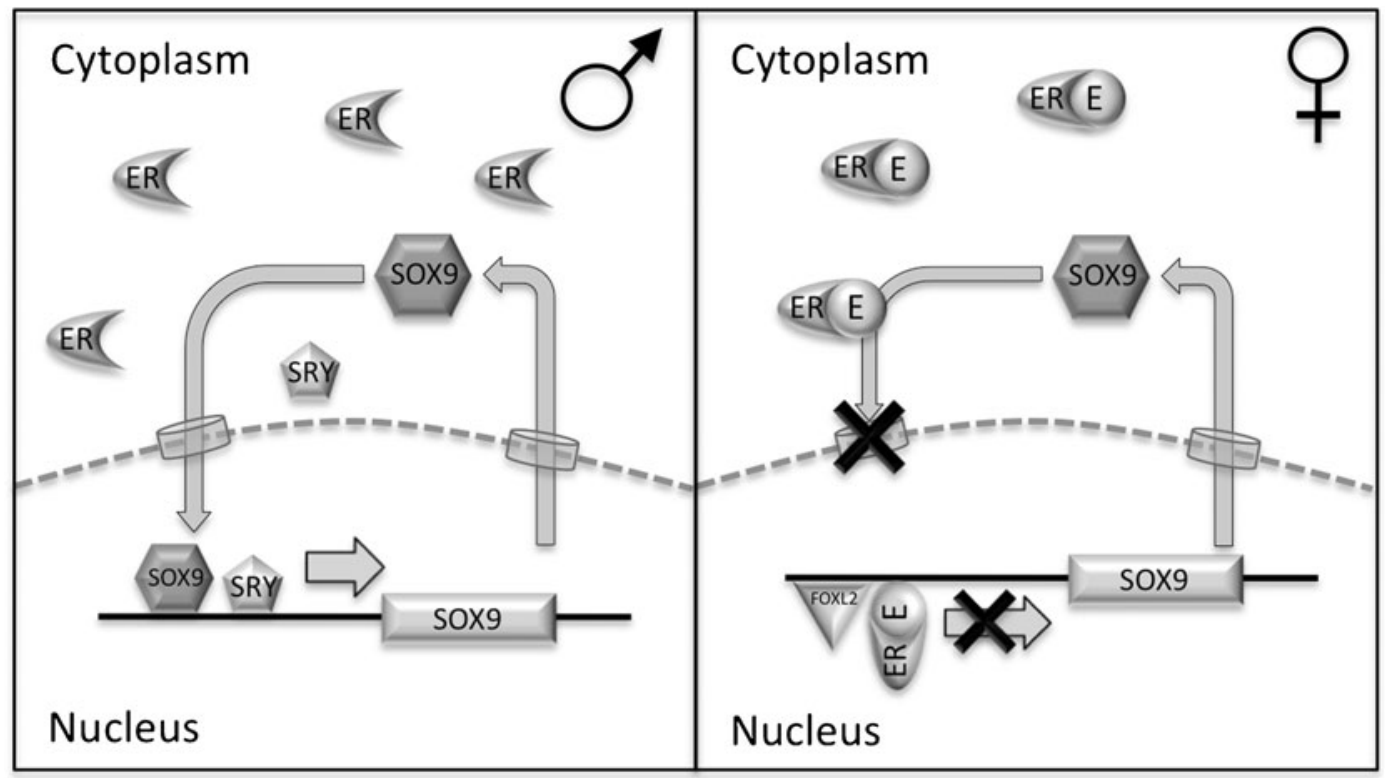

Fig. 3 Left panel: In the absence of estrogen $(E)$, the estrogen receptors $(E R)$ are not activated and remain cytoplasmic. SOX9 is able to translocate to the nucleus where it acts with SRY to reinforce its own transcription and activate Sertoli cell differentiation. Right panel: In the presence of estrogen, estrogen receptors become activated. Activated estrogen

directly mediate its transcription, could explain the primary mechanism by which estrogen establishes sex in nonmammalian vertebrates.

Further investigations are needed to determine how estrogen mediates the subcellular localization of SOX9 within the somatic cells. SOX9 contains two defined nuclear localization signals (NLS) found in the C-and $\mathrm{N}$-termini that are $100 \%$ conserved between mouse, human, and the wallaby (Pask et al. 2002). Active transport through nucleopore complex is facilitated in part by importin- $\beta$, binding directly to the C-terminal NLS (Sim et al. 2008). This binding is enhanced by phosphorylation of SOX9 by phosphokinase A, facilitating increased nuclear import (Malki et al. 2005). The N-terminal NLS binds calmodulin, another factor that facilitates nuclear transport of SOX9 (Argentaro et al. 2003). SOX9 is also subject to SUMOylation and ubiquitination (Sim et al. 2008). SUMOylation has been shown to regulate nucleocytoplasmic trafficking of several proteins while ubiquitination marks proteins for degradation. SUMOylation of SOX9 in COS7 cells has been shown to alter its subnuclear localisation and transcriptional activity (Hattori et al. 2006). Estrogen may affect one or many of these receptors $(E R+E)$ block any SOX9 protein that is made from entering the nucleus, preventing $S O X 9$ upregulation, and resulting in granulosa cell development. Activated estrogen receptor complexes can also move into the nucleus and along with FOXL2, suppress SOX9 transcription by directly binding to the SOX9 enhancer, TESCO

different pathways to regulate the subcellular localization and activity of SOX9.

\section{A conserved model for determining vertebrate somatic cell fate}

While the switch mechanisms that trigger the development of the ovary or testis pathways vary widely among vertebrates, the fundamental control mechanisms regulating somatic cell fate share many commonalities. This suggests a highly conserved and antagonistic relationship between SOX9 and estrogen-driving Sertoli cell and granulosa cell differentiation, respectively. In mammals, the somatic cell decision is initially determined by the presence or absence of SRY. When SRY is present, SOX9 is upregulated and can translocate to the nucleus to activate Sertoli cell differentiation. In females, in the absence of SRY, SOX9 is not upregulated and the granulosa cell program is initiated. While it is yet to be shown if estrogen plays a critical role in early mammalian ovary formation outside of the rodent lineage, estrogen is essential for maintaining granulosa cell fate in the mature gonads, possibly by ensuring that 
any SOX9 protein produced remains trapped in the cytoplasm. In nonmammalian vertebrates, the primary sex-determining mechanism, be it GSD or ESD, leads to either the presence or absence of CYP19 expression. In the presence of aromatase and estrogen, basal SOX9 cannot enter the nucleus and the Sertoli cell program is blocked. In the absence of aromatase and estrogen, SOX9 can translocate to the nucleus, trigger its own upregulation, and initiate Sertoli cell development. More work is needed to confirm this model and determine the precise mechanism by which activated estrogen receptors mediate the subcellular localization of SOX9. However, these findings provide a simple explanation for the dramatic switch in vertebrate sex determination mechanisms from primarily hormonal control to primarily genetic control, converging through the modulation of SOX9.

\section{References}

Arai Y, Mori T, Suzuki Y, Bern HA (1983) Long-term effects of perinatal exposure to sex steroids and diethylstilbestrol on the reproductive system of male mammals. Int Rev Cytol 84:235-268

Argentaro A, Sim H, Kelly S, Preiss S, Clayton A, Jans DA, Harley VR (2003) A SOX9 defect of calmodulin-dependent nuclear import in campomelic dysplasia/autosomal sex reversal. J Biol Chem 278(36):33839-33847

Bagheri-Fam S, Sinclair AH, Koopman P, Harley VR (2010) Conserved regulatory modules in the Sox 9 testis-specific enhancer predict roles for SOX, TCF/LEF, Forkhead, DMRT, and GATA proteins in vertebrate sex determination. Int J Biochem Cell Biol 42(3):472-477

Bishop CE, Whitworth DJ, Qin Y, Agoulnik AI, Agoulnik IU, Harrison WR, Behringer RR, Overbeek PA (2000) A transgenic insertion upstream of sox 9 is associated with dominant $\mathrm{XX}$ sex reversal in the mouse. Nat Genet 26(4):490-494

Bowles J, Knight D, Smith C, Wilhelm D, Richman J, Mamiya S, Yashiro K, Chawengsaksophak K, Wilson MJ, Rossant J, Hamada H, Koopman P (2006) Retinoid signaling determines germ cell fate in mice. Science 312(5773):596-600

Britt KL, Findlay JK (2003) Regulation of the phenotype of ovarian somatic cells by estrogen. Mol Cell Endocrinol 202(1-2):11-17

Britt KL, Drummond AE, Dyson M, Wreford NG, Jones ME, Simpson ER, Findlay JK (2001) The ovarian phenotype of the aromatase knockout (ArKO) mouse. J Steroid Biochem Mol Biol 79(1-5):181-185

Britt KL, Kerr J, O'Donnell L, Jones ME, Drummond AE, Davis SR, Simpson ER, Findlay JK (2002) Estrogen regulates development of the somatic cell phenotype in the eutherian ovary. FASEB J 16(11):1389-1397

Britt KL, Stanton PG, Misso M, Simpson ER, Findlay JK (2004) The effects of estrogen on the expression of genes underlying the differentiation of somatic cells in the murine gonad. Endocrinology 145(8):3950-3960

Burns RK (1955) Experimental reversal of sex in the gon ads of the opossum didelphis Virginiana. Proc Natl Acad Sci U S A 41(9):669-676

Calatayud NE, Pask AJ, Shaw G, Richings NM, Osborn S, Renfree MB (2010) Ontogeny of the oestrogen receptors ESR1 and ESR2 during gonadal development in the tammar wallaby, Macropus eugenii. Reproduction 139(3):599-611

Carlsen E, Giwercman A, Keiding N, Skakkebaek NE (1992) Evidence for decreasing quality of semen during past 50 years. BMJ 305(6854):609-613

Chassot AA, Gregoire EP, Magliano M, Lavery R, Chaboissier MC (2008a) Genetics of ovarian differentiation: Rspo1, a major player. Sex Dev 2(4-5):219-227

Chassot AA, Ranc F, Gregoire EP, Roepers-Gajadien HL, Taketo MM, Camerino G, de Rooij DG, Schedl A, Chaboissier MC (2008b) Activation of beta-catenin signaling by Rspo1 controls differentiation of the mammalian ovary. Hum Mol Genet 17(9):1264-1277

Couse JF, Korach KS (1999) Estrogen receptor null mice: what have we learned and where will they lead us? Endocr Rev 20(3):358-417

Coveney D, Shaw G, Renfree MB (2001) Estrogen-induced gonadal sex reversal in the tammar wallaby. Biol Reprod 65(2):613-621

Crozat K, Guiton R, Guilliams M, Henri S, Baranek T, SchwartzCornil I, Malissen B, Dalod M (2010) Comparative genomics as a tool to reveal functional equivalences between human and mouse dendritic cell subsets. Immunol Rev 234(1):177-198

de Santa Barbara P, Moniot B, Poulat F, Berta P (2000) Expression and subcellular localization of SF-1, SOX9, WT1, and AMH proteins during early human testicular development. Dev Dyn 217(3):293-298

El Jamil A, Kanhoush R, Magre S, Boizet-Bonhoure B, PenradMobayed M (2008) Sex-specific expression of SOX9 during gonadogenesis in the amphibian Xenopus tropicalis. Dev Dyn 237(10):2996-3005

Ferguson-Smith M (2007) The evolution of sex chromosomes and sex determination in vertebrates and the key role of DMRT1. Sex Dev 1(1):2-11

Fisher CR, Graves KH, Parlow AF, Simpson ER (1998) Characterization of mice deficient in aromatase (ArKO) because of targeted disruption of the cyp19 gene. Proc Natl Acad Sci U S A 95(12):6965-6970

Garverick HA, Juengel JL, Smith P, Heath DA, Burkhart MN, Perry GA, Smith MF, McNatty KP (2010) Development of the ovary and ontongeny of mRNA and protein for P450 aromatase (arom) and estrogen receptors (ER) alpha and beta during early fetal life in cattle. Anim Reprod Sci 117(1-2):24-33

Giwercman A, Carlsen E, Keiding N, Skakkebaek NE (1993) Evidence for increasing incidence of abnormalities of the human testis: a review. Environ Health Perspect 101(Suppl 2):65-71

Harry JL, Koopman P, Brennan FE, Graves JA, Renfree MB (1995) Widespread expression of the testis-determining gene SRY in a marsupial. Nat Genet 11(3):347-349

Hattori T, Eberspaecher H, Lu J, Zhang R, Nishida T, Kahyo T, Yasuda H, de Crombrugghe B (2006) Interactions between PIAS proteins and SOX9 result in an increase in the cellular concentrations of SOX9. J Biol Chem 281(20):14417-14428 
Heikkila M, Peltoketo H, Vainio S (2001) Wnts and the female reproductive system. J Exp Zool 290(6):616-623

Koopman P, Gubbay J, Vivian N, Goodfellow P, Lovell-Badge R (1991) Male development of chromosomally female mice transgenic for Sry. Nature 351(6322):117-121

Koubova J, Menke DB, Zhou Q, Capel B, Griswold MD, Page DC (2006) Retinoic acid regulates sex-specific timing of meiotic initiation in mice. Proc Natl Acad Sci U S A 103 (8):2474-2479

Lu Y, Huggins P, Bar-Joseph Z (2009) Cross species analysis of microarray expression data. Bioinformatics 25(12):1476-1483

Luo ZX, Yuan CX, Meng QJ, Ji Q (2011) A Jurassic eutherian mammal and divergence of marsupials and placentals. Nature 476(7361):442-445

Malki S, Nef S, Notarnicola C, Thevenet L, Gasca S, Mejean C, Berta P, Poulat F, Boizet-Bonhoure B (2005) Prostaglandin D2 induces nuclear import of the sex-determining factor SOX9 via its cAMP-PKA phosphorylation. EMBO J 24 (10):1798-1809

Matson CK, Murphy MW, Sarver AL, Griswold MD, Bardwell VJ, Zarkower D (2011) DMRT1 prevents female reprogramming in the postnatal mammalian testis. Nature 476 (7358):101-104

Matsuda M, Nagahama Y, Shinomiya A, Sato T, Matsuda C, Kobayashi T, Morrey CE, Shibata N, Asakawa S, Shimizu N, Hori H, Hamaguchi S, Sakaizumi M (2002) DMY is a Y-specific DM-domain gene required for male development in the medaka fish. Nature 417(6888):559-563

Morais da Silva S, Hacker A, Harley V, Goodfellow P, Swain A, Lovell-Badge R (1996) Sox9 expression during gonadal development implies a conserved role for the gene in testis differentiation in mammals and birds. Nat Genet 14(1):62-68

Nakamura M (2010) The mechanism of sex determination in vertebrates-are sex steroids the key-factor? J Exp Zool A Ecol Genet Physiol 313(7):381-398

Notarnicola C, Malki S, Berta P, Poulat F, Boizet-Bonhoure B (2006) Transient expression of SOX9 protein during follicular development in the adult mouse ovary. Gene Expr Patterns 6(7):695-702

Pannetier M, Mandon-Pepin B, Copelli S, Fellous M (2004) Molecular aspects of female and male gonadal development in mammals. Pediatr Endocrinol Rev 1(3):274-287

Pask A, Graves JA (2001) Sex chromosomes and sex-determining genes: insights from marsupials and monotremes. EXS 91:71-95

Pask AJ, Harry JL, Graves JA, O'Neill RJ, Layfield SL, Shaw G, Renfree MB (2002) SOX9 has both conserved and novel roles in marsupial sexual differentiation. Genesis 33(3):131-139

Pask AJ, Calatayud NE, Shaw G, Wood WM, Renfree MB (2010) Oestrogen blocks the nuclear entry of SOX9 in the developing gonad of a marsupial mammal. BMC Biol 8(1):113

Pounds S, Gao CL, Johnson RA, Wright KD, Poppleton H, Finkelstein D, Leary SE, Gilbertson RJ (2011) A procedure to statistically evaluate agreement of differential expression for cross-species Genomics. Bioinformatics 27(15):2098-2103

Qin Y, Kong LK, Poirier C, Truong C, Overbeek PA, Bishop CE (2004) Long-range activation of Sox9 in odd sex (Ods) mice. Hum Mol Genet 13(12):1213-1218

Quirke LD, Juengel JL, Tisdall DJ, Lun S, Heath DA, McNatty KP (2001) Ontogeny of steroidogenesis in the fetal sheep gonad. Biol Reprod 65(1):216-228
Ramsey M, Crews D (2009) Steroid signaling and temperaturedependent sex determination - reviewing the evidence for early action of estrogen during ovarian determination in turtles. Semin Cell Dev Biol 20(3):283-292

Renfree MB, O WS, Short RV, Shaw G (1996) Sexual differentiation of the urogenital system of the fetal and neonatal tammar wallaby, Macropus eugenii. Anat Embryol (Berl) 194(2):111-134

Sanchez DH, Pieckenstain FL, Szymanski J, Erban A, Bromke M, Hannah MA, Kraemer U, Kopka J, Udvardi MK (2011) Comparative functional genomics of salt stress in related model and cultivated plants identifies and overcomes limitations to translational genomics. PLoS One 6(2):e17094

Sekido R, Lovell-Badge R (2008) Sex determination involves synergistic action of SRY and SF1 on a specific Sox9 enhancer. Nature 453(7197):930-934

Sim H, Argentaro A, Harley VR (2008) Boys, girls and shuttling of SRY and SOX9. Trends Endocrinol Metabol 19(6):213-222

Sinclair AH, Berta P, Palmer MS, Hawkins JR, Griffiths BL, Smith MJ, Foster JW, Frischauf AM, Lovell-Badge R, Goodfellow PN (1990) A gene from the human sexdetermining region encodes a protein with homology to a conserved DNA-binding motif. Nature 346(6281):240-244

Smith CA, Roeszler KN, Ohnesorg T, Cummins DM, Farlie PG, Doran TJ, Sinclair AH (2009) The avian Z-linked gene DMRT1 is required for male sex determination in the chicken. Nature 461(7261):267-271

Solari AJ (1994) Sex chromosomes and sex determination in vertebrates. CRC Press, Boca Raton

Sridevi P, Chaitanya RK, Dutta-Gupta A, Senthilkumaran B (2011) FTZ-F1 and FOXL2 up-regulate catfish brain aromatase gene transcription by specific binding to the promoter motifs. Biochim Biophys Acta

Toda K, Takeda K, Okada T, Akira S, Saibara T, Kaname T, Yamamura K, Onishi S, Shizuta Y (2001) Targeted disruption of the aromatase P450 gene (Cyp19) in mice and their ovarian and uterine responses to 17 beta-oestradiol. $\mathrm{J}$ Endocrinol 170(1):99-111

Toppari J (2008) Environmental endocrine disrupters. Sex Dev 2(4-5):260-267

Uda M, Ottolenghi C, Crisponi L, Garcia JE, Deiana M, Kimber W, Forabosco A, Cao A, Schlessinger D, Pilia G (2004) Fox12 disruption causes mouse ovarian failure by pervasive blockage of follicle development. Hum Mol Genet 13(11):1171-1181

Uhlenhaut NH, Jakob S, Anlag K, Eisenberger T, Sekido R, Kress J, Treier AC, Klugmann C, Klasen C, Holter NI, Riethmacher D, Schutz G, Cooney AJ, Lovell-Badge R, Treier M (2009) Somatic sex reprogramming of adult ovaries to testes by FOXL2 ablation. Cell 139(6):1130-1142

Vainio S, Heikkila M, Kispert A, Chin N, McMahon AP (1999) Female development in mammals is regulated by Wnt-4 signalling. Nature 397(6718):405-409

Wilhelm D, Palmer S, Koopman P (2007) Sex determination and gonadal development in mammals. Physiol Rev 87(1):1-28

Yoshimoto S, Okada E, Umemoto H, Tamura K, Uno Y, Nishida-Umehara C, Matsuda Y, Takamatsu N, Shiba T, Ito M (2008) A W-linked DM-domain gene, DM-W, participates in primary ovary development in Xenopus laevis. Proc Natl Acad Sci U S A 105(7):2469-2474 